\title{
Concentration of selenium in plasma and erythrocytes during total parenteral nutrition in Crohn's disease
}

\author{
S JACOBSON AND L-O PLANTIN
}

From the Department of Surgery and the Research Centre, Huddinge Hospital, Karolinska Institute, Stockholm, Sweden

SUMMARY Plasma- and erythrocyte-selenium concentrations were determined in five consecutive patients with Crohn's disease given preoperative total parenteral nutrition - nil per os - for a mean period of 34 days per patient. No blood components were administered during the total parenteral nutriton. Before the total parenteral nutrition the plasma-selenium level and, to a less extent, the erythrocyte-selenium levels were below the reference values. After three weeks of total parenteral nutrition both concentrations had fallen. There were, however, clinical and biochemical signs of improvement during the total parenteral nutrition, as indicated by an increase in body weight, P-albumin and P-transferrin. In one female patient given 39 days of preoperative total parenteral nutrition containing $0.06 \mu \mathrm{mol}(5 \mu \mathrm{g})$ selenium per $24 \mathrm{~h}$ the decreasing levels of plasma-selenium and erythrocyte-selenium were both correlated to the duration of the total parenteral nutrition ( $r=0.87$ and 0.96 , respectively). The results suggest that total parenteral nutrition patients may be at risk for selenium deficiency, and that a supplementary administration of selenium via total parenteral nutrition may be required.

Total parenteral nutrition has become a valuable aid in the care of patients with Crohn's disease. ${ }^{12}$ As many patients with Crohn's disease show multiple and sometimes severe nutritional deficiencies, ${ }^{3}$ the total parenteral nutrition solutions should not lack any essential nutrient that might aggravate an existing deficiency.

Selenium deficiency has been observed in adults receiving parenteral nutrition, ${ }^{45}$ and may cause fatal cardiomyopathy during such a treatment. ${ }^{6}$ As we have found very low concentrations of selenium in whole blood in patients with Crohn's disease, ${ }^{7}$ the present study of both plasma and erythrocyte concentrations of selenium in such patients receiving total parenteral nutrition, including commercially available solutions, was performed with an improved method for selenium analysis.

\section{Methods}

PATIENTS

The series for this study consisted of five consecutive patients with Crohn's disease (one man and four

Address for correspondence: Stefan Jacobson, MD, Department of Surgery, Huddinge Hospital, S-141 86 Huddinge, Sweden.

Received for publication 23 March 1984 women), who were given total parenteral nutrition (nil per os), without blood transfusion or blood components, for more than three weeks. The total parenteral nutrition was administered preoperatively on clinical grounds. The diagnosis of Crohn's disease was based on the findings at clinical, radiographic and histologic examinations. ${ }^{89}$ Bowel resection was performed on total parenteral nutrition days 23-56. The period of the study consisted only of the preoperative days of total parenteral nutrition (mean, 34 days per patient; range, 22-55 days per patient).

The clinical data relating to the patients are presented in Table 1. Four of the patients had had

Table 1 Clinical data for five patients with Crohn's disease on introduction of total parenteral nutrition (TPN)

\begin{tabular}{|c|c|c|}
\hline & Mean & $S D$ \\
\hline Age (yr) & 39 & 13 \\
\hline Height (m) & 1.67 & 0.06 \\
\hline Body weight (kg) & 48 & 6 \\
\hline Body mass index* (units) & $17 \cdot 1$ & $1 \cdot 5$ \\
\hline Crohn's disease activity index (units) ${ }^{33}$ & 329 & 104 \\
\hline
\end{tabular}


an operation. At the time the total parenteral nutrition was introduced one patient had jejunocolitis (after several resections of the small intestine and the ascending colon), two had ileitis (after ileocecal resections), one ileocolitis and one colitis (after resection of the sigmoid colon). Two patients were given prednisolone; the initial doses of 12.5 and $40 \mathrm{mg} / 24 \mathrm{~h}$ were gradually reduced during the preoperative days of total parenteral nutrition.

\section{INFUSION SOLUTIONS AND PROCEDURE}

The infusion solutions included amino acids (Vamin with glucose, KabiVitrum AB, Stockholm, Sweden),${ }^{10}$ carbohydrates, fat emulsion (Intralipid $10 \%$, KabiVitrum) ${ }^{11}$ electrolytes, trace elements (Addamel, KabiVitrum) and vitamins (Soluvit and Vitalipid Adult, KabiVitrum). ${ }^{12}$ The total parenteral nutrition regimens provided $9 \cdot 8-13 \cdot 1 \mathrm{MJ}$ $(2350-3100 \mathrm{kcal})$ of energy per $24 \mathrm{~h}(8 \cdot 8-11 \cdot 5$ non-protein $\mathrm{MJ} / 24 \mathrm{~h}$ ), including $56 \mathrm{~g}$ fat, 287.5$437.5 \mathrm{~g}$ glucose, $112.5 \mathrm{~g}$ fructose, 9.4-14.1 g nitrogen, $11.25 \mathrm{~g}$ glycerol and $4.5 \mathrm{~g}$ sorbitol.

The intravenous infusions were given for about 14 hours daily $(08.00-22.00 \mathrm{~h})$ by gravity drip through a central venous catheter. ${ }^{13}$ In two patients 0.51 of Intralipid $10 \%$, including the vitamins, was given from 08.00 to $10.00 \mathrm{~h}$, followed, until $22.00 \mathrm{~h}$, by a mixture of the other infusion components, delivered from the pharmacy in a 3-litre plastic bag (Travenol, Thetford, Norfolk, England). In the other three patients the fat emulsion (given from 08.00 to $14.00 \mathrm{~h}$ ) and the mixture of the other infusion components (given from 08.00 to $22.00 \mathrm{~h}$ ) were mixed when passing through the central venous catheter. To reduce the risk of central venous catheter-related thrombosis all the patients were given heparin intravenously, $5000 \mathrm{IU} / 6 \mathrm{~h}^{14}$

\section{ANALYTICAL METHODS}

Venous blood samples were drawn after an overnight fast (12-14 h) before total parenteral nutrition was introduced, and between 07.00 and $08.00 \mathrm{~h}$ before the daily infusion was started - at intervals during total parenteral nutrition. The concentrations of albumin, haptoglobin, orosomucoid, and transferrin in the blood plasma (P-) were determined by the conventional methods used at Huddinge Hospital, as also were the haemoglobin concentration in blood.

The selenium concentration in the samples was determined by neutron activation analysis. ${ }^{15}$ Approximately $0.5 \mathrm{~g}$ of plasma and $0.5 \mathrm{~g}$ of erythrocytes were freeze-dried in quartz ampoules under conditions designed to avoid contamination. The quartz ampoules were sealed in an oxygenhydrogen flame and then irradiated in the Norwegian nuclear reactor JEEP II at Kjeller for one week at a flux of $2 \times 10^{13} \mathrm{n} \mathrm{cm}^{-2} \mathrm{~s}^{-1}$. The samples were dissolved in acids. Selenium was precipitated and counted as described elsewhere. ${ }^{15}$

The method of statistical analysis of the results was Student's $t$ test for paired and unpaired data. Differences were considered to be significant at the level $\mathrm{p}<0 \cdot 05$. Regression lines were calculated by the method of least squares. All the results are reported as the mean $\pm \mathrm{SD}$.

\section{Results}

During total parenteral nutrition all five patients displayed clinical remission - as judged from their well-being, relief of abdominal pain and abatement of diarrhoea. Throughout the period of preoperative total parenteral nutrition the body weight increased significantly from $48 \pm 6$ to $51 \pm 7 \mathrm{~kg}$.

The results of the biochemical analyses are summarised in Table 2. Throughout the period of preoperative total parenteral nutrition the $P$ albumin concentration increased from $30 \pm 3$ to $38 \pm 4$ $\mathrm{g} / \mathrm{l}$; the numerical decrease in P-orosomucoid from $1.7 \pm 0.5$ to $1.3 \pm 0.4 \mathrm{~g} / \mathrm{l}$ was not significant $(\mathrm{p}=0.08)$.

The results of the analyses of the selenium

Table 2 Blood (B-) concentration of haemoglobin and plasma $\left(P_{-}\right)$concentrations of three proteins measured during TPN in the five patients with Crohn's disease

\begin{tabular}{|c|c|c|c|c|c|c|c|c|c|c|c|c|c|}
\hline \multirow[b]{3}{*}{ Component } & & & & \multicolumn{9}{|c|}{ During TPN } & \multirow{3}{*}{$\begin{array}{l}\text { Reference } \\
\text { range }\end{array}$} \\
\hline & \multicolumn{3}{|c|}{ Before IPN } & \multicolumn{3}{|c|}{ Days 7-10 } & \multicolumn{3}{|l|}{ Day 15} & \multicolumn{3}{|c|}{ Days 21-23 } & \\
\hline & Mean & $S D$ & $n$ & Mean & $S D$ & $n$ & Mean & $S D$ & $n$ & Mean & $S D$ & $n$ & \\
\hline B-haemoglobin $(\mathrm{g} / \mathrm{l})$ & 104 & 9 & 5 & 104 & 12 & 5 & 109 & 5 & 5 & 116 & 15 & 4 & $115-165$ \\
\hline P-albumin $(g / l)$ & 30 & 3 & 5 & 33 & 3 & 5 & $35^{*}$ & 3 & 5 & $36^{*}$ & 5 & 4 & $38-55$ \\
\hline P-haptoglobin (g/l) & $2 \cdot 9$ & $1 \cdot 0$ & 5 & $2 \cdot 6^{*}$ & $1 \cdot 0$ & 5 & $3 \cdot 0$ & $1 \cdot 7$ & 5 & $2 \cdot 1^{*}$ & $1 \cdot 2$ & 4 & $0.4-2 \cdot 0$ \\
\hline
\end{tabular}

* Significant difference from the value before TPN $(p<0 \cdot 05)$. 
concentrations in plasma and erythrocytes are summarised in Table 3. After three weeks of total parenteral nutrition the plasma-selenium and erythrocyte-selenium concentrations had decreased, even though both were below the reference values when total parenteral nutrition was introduced. In one female patient, who had the highest initial concentration of erythrocyte-selenium of all the patients, the concentrations of plasma-selenium and erythrocyte-selenium were both correlated to the duration of the preoperative total parenteral nutrition ( $r=0.87$ and $r=0.96$, respectively) (Figure). Four analyses of the total parenteral nutrition solutions showed that she had received about $5 \mu \mathrm{g}(0.06 \mu \mathrm{mol})$ of selenium per 24 hours, 1 $\mu \mathrm{g}$ of which was present in the 0.51 of Intralipid $10 \%$, including the vitamins.

\section{Discussion}

Depletion of trace elements, including chromium, copper, molybdenum, selenium and zinc, has been observed in patients receiving their total nutritional needs from intravenous solutions. ${ }^{46-19}$ One trace element that is not added to total parenteral nutrition solutions in Sweden and many other parts of the world is selenium; this is an essential component of the cytosol enzyme, glutathione peroxidase (GSH-Px), which is concerned in the metabolism of hydrogen peroxide. ${ }^{20-22}$

The nutritional status in respect of selenium can be determined by measuring the selenium concentration and the GSH-Px activity in the blood. ${ }^{20}$ The blood selenium concentration and the GSH-Px activity have been found to be positively correlated in animals and healthy New Zealand ${ }^{23} 24$ and American $^{25}$ populations.

A positive correlation between erythrocyte GSHPx activity and plasma selenium concentration has been found in patients given parenteral nutrition but

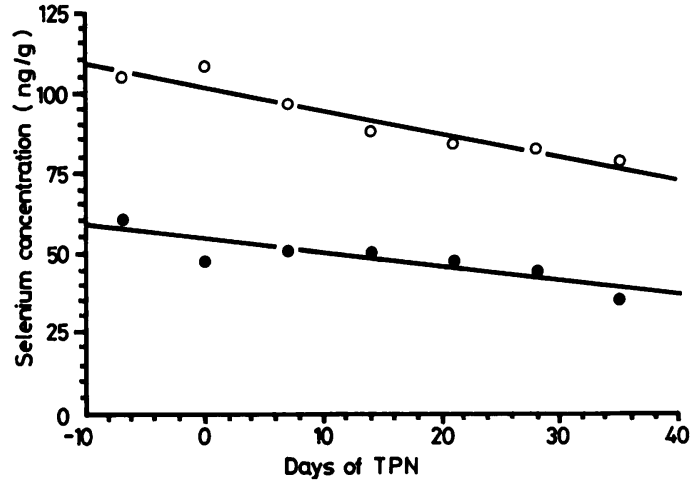

Figure In one female patient given preoperative total parenteral nutrition for 39 days the concentrations of selenium in erythrocytes $\left(0, y_{1}\right)$ and in plasma $\left(0, y_{2}\right)$, were correlated to the duration of the total parenteral nutrition $(x)$, as described by the regression equations: $y_{1}=102-0.722 x$ and $y_{2}=54.4-0.438 x$, respectively. Corresponding correlation coefficients (r) were 0.96 and $0 \cdot 87$.

not between erythrocyte selenium concentration and GSH-Px activity. ${ }^{5}$ This may be because only a small part of the erythrocyte selenium is bound to GSH-Px, and that these two pools of erythrocyte selenium may change at different rates. ${ }^{26}$

In the Crohn's disease patients of the present study there was a decrease in the plasma and erythrocyte concentrations of selenium during total parenteral nutrition, including commercially available infusion solutions but no supplementary selenium. This decrease is remarkable in view of the fact that the concentrations of selenium in the plasma and the erythrocytes point to selenium deficiency already at the time that total parenteral nutrition was introduced. The clinical significance of this degree of low blood selenium concentrations is,

Table 3 Plasma (P-) and erythrocyte (E-) concentrations of selenium measured during TPN in the five patients with Crohn's disease

\begin{tabular}{|c|c|c|c|c|c|c|c|c|c|c|c|c|c|c|c|c|c|c|c|c|c|c|}
\hline \multirow[b]{3}{*}{ Component } & \multirow{2}{*}{\multicolumn{3}{|c|}{ Before TPN }} & \multicolumn{16}{|c|}{ During TPN } & \multirow{2}{*}{\multicolumn{3}{|c|}{$\begin{array}{l}\text { Reference } \\
\text { value }\end{array}$}} \\
\hline & & & & \multicolumn{3}{|c|}{ Day 7-10 } & \multicolumn{3}{|c|}{ Day 15} & \multicolumn{3}{|c|}{ Days 21-22 } & \multicolumn{3}{|c|}{ Days 27-29 } & \multicolumn{2}{|c|}{ Day 36} & \multicolumn{2}{|c|}{ Day 50} & & & \\
\hline & Mean & $S D$ & $n$ & Mean & $S D$ & $n$ & Mean & $S D$ & $n$ & Mean & $S D$ & $n$ & Mean & $S D$ & $n$ & Mean & $n$ & Mean & $n$ & Mean & $S D$ & $n$ \\
\hline $\begin{array}{l}\text { P-selenium } \\
\text { (ng/g) } \\
\text { E-selenium }\end{array}$ & 45 & 15 & 5 & $39^{*}$ & 17 & 4 & 45 & 19 & 3 & $37^{*}$ & 12 & 5 & $39^{*}$ & 16 & 3 & 39 & 2 & 43 & 1 & $81 \dagger$ & 14 & 50 \\
\hline$(\mathrm{ng} / \mathrm{g})$ & 78 & 17 & 5 & 70 & 22 & 4 & 72 & 15 & 3 & $65^{*}$ & 12 & 5 & 66 & 17 & 3 & 71 & 2 & 56 & 1 & $100^{*}$ & 19 & 50 \\
\hline
\end{tabular}

* Significant difference from the value before TPN $(\mathrm{p}<0.05)$.

$\dagger$ Significant difference from the value before TPN $(\mathrm{p}<0.001)$. 
however, unknown.

Though the total parenteral nutrition regimen obviously aggravated the deficiency of selenium, there was clinical and biochemical evidence of a nutritional improvement during the total parenteral nutrition, as indicated by the increase in body weight, P-albumin and P-transferrin. The possible concomitant abatement of the inflammation of the bowel, as reflected in the changes in the biochemical variables studied, was less convincing, as there was a decrease only in P-haptoglobin, and no significant change in $\mathrm{P}$-orosomucoid.

The female patient represented in the Figure had an erythrocyte volume fraction of about $35 \%$ throughout the 39 days of preoperative total parenteral nutrition. If a blood volume of 5 litres is assumed, the 24-hour loss of selenium in this patient during the total parenteral nutrition would have been $16 \mathrm{nmol}(1.3 \mu \mathrm{g})$ from the erythrocytes and 18 $\mathrm{nmol}(1.4 \mu \mathrm{g})$ from the blood plasma, or $34 \mathrm{nmol}$ $(2.7 \mu \mathrm{g})$ from the whole blood volume. In Crohn's disease patients on a similar selenium-poor total parenteral nutrition regimen to that of the present study the 24-hour urinary selenium excretion was 43-57 nmol (3-5 $\mu \mathrm{g}) ;{ }^{13}$ this is of the same magnitude as the calculated loss from the blood compartment of the female patient in question.

Neither a low dietary selenium intake nor a low blood selenium concentration has been found to be related to any specific pathologic condition in man. ${ }^{5}$ A low selenium concentration in serum, however, has been associated with an increased risk of gastrointestinal and prostatic cancer. ${ }^{27} \mathrm{New}$ Zealanders who consume less than $50 \mu \mathrm{g}$ of dietary selenium a day were not observed to have any specific disease ${ }^{24}$ whereas Chinese children and women of child-bearing age living in a specific region and consuming less than $30 \mu \mathrm{g}$ selenium/day frequently developed a cardiomyopathy called Keshan's disease. ${ }^{28} 29$ This disease can be prevented, though not cured, by dietary supplementation of sodium selenite.

The total parenteral nutrition solutions and additives used in this study provided only about $5 \mu \mathrm{g}$ of selenium per 24 hours. In total parenteral nutrition solutions used in USA, however, up to $300 \mu \mathrm{g}$ of selenium per litre has been found as a contaminant. ${ }^{30} 31$

Selenium supplementation in patients on long term parenteral nutrition has received little attention, and no intravenous selenium preparation is commercially available in Sweden.

Because of the inter-subject variability and the potential toxicity of selenium ${ }^{32}$ it has been recommended that an assessment of the selenium status should be performed before adding the element to the infusion solution, and repeated at intervals during the administration of supplementary selenium. ${ }^{5}$

In view of the fact that, despite initially subnormal values, our patients showed a decrease in the plasma and erythrocyte selenium concentrations over so short a period of total parenteral nutrition as three weeks, and as our infusion solutions are poor in selenium, it would seem important to administer the element to selenium-deficient total parenteral nutrition patients.

\section{References}

1 Milewski $\mathrm{PH}$, Irving $\mathrm{MH}$. Parenteral nutrition in Crohn's disease. Dis Colon Rectum 1980; 23: 395-400.

2 Lehr L, Schober O, Hundeshagen H, Pichlmayr R. Total body potassium depletion and the need for preoperative nutritional support in Crohn's disease. Ann Surg 1982; 196: 709-14.

3 Driscoll Jr RH, Rosenberg IH. Total parenteral nutrition in inflammatory bowel disease. Med Clin $N$ Am 1978; 62: 185-201.

4 van Rij AM, Thomson CD, McKenzie JM, Robinson MF. Selenium deficiency in total parenteral nutrition. Am J Clin Nutr 1979; 32: 2076-85.

5 Lane HW, Barroso AO, Englert D, Dudrick SJ, MacFadyen Jr BS. Selenium status of seven chronic intravenous hyperalimentation patients. $J$ Parent Ent Nutr 1982; 6: 426-31.

6 Fleming CR, Lie JT, McCall JT, O'Brien JF, Baillie EE, Thistle JL. Selenium deficiency and fatal cardiomyopathy in a patient on home parenteral nutrition. Gastroenterology 1982; 83: 689-93.

7 Jacobson S, Plantin LO. Spårelementkoncentrationer i helblod vid långvarig total parenteral nutrition. Svensk Kirurgi 1979; 37: 168-9.

8 Price AB, Morson BC. Inflammatory bowel disease. The surgical pathology of Crohn's disease and ulcerative colitis. Hum Pathol 1975; 6: 7-29.

9 Goldberg HI, Caruthers Jr SB, Nelson JA, Singleton JW. Radiographic findings of the national cooperative Crohn's disease study. Gastroenterology 1979; 77: 925-37.

10 Jacobson S. Serum concentrations and urinary excretion of amino acids during total parenteral nutrition after abdominal surgery. J Parent Ent Nutr 1982; 6: 204-13.

11 Grotte G, Jacobson S, Wretlind A. Lipid emulsions and technique of peripheral administration in parenteral nutrition. In: Fischer JE, ed. Total parenteral nutrition. Boston: Little, Brown \& Co, 1976: 335-62.

12 Jacobson S, Wester PO. Balance study of twenty trace elements during total parenteral nutrition in man. $B r J$ Nutr 1977; 37: 107-26. 
13 Jacobson S, Plantin LO, Carlmark B. Urinary excretion and blood concentrations of trace elements and electrolytes during total parenteral nutrition in Crohn's disease. Dig Dis Sci 1984; 29: 606-13.

14 Brismar B, Hårdstedt $\mathrm{C}$, Jacobson $\mathrm{S}$, Kager L, Malmborg AS. Reduction of catheter-associated thrombosis in parenteral nutrition by intravenous heparin therapy. Arch Surg 1982; 117: 1196-9.

15 Plantin LO, Meurling S, Strandvik B. Selenium levels in Swedish children determined with a simple neutron activation analysis method. In Mineral elements ' 80. Proceedings, part 2, of a Nordic symposium on soil-plant-animal-man interrelationships and implications to human health. Helsinki: Mineral elements ' 80 , Box 330, 00101 Helsinki 10, 1981: 453-7.

16 Jeejeebhoy KN, Langer B, Tsallas G, Chu RC, Kuksis $A$, Anderson GH. Total parenteral nutrition at home: studies in patients surviving 4 months to 5 years. Gastroenterology 1976; 71: 943-53.

17 Solomons NW, Layden TJ, Rosenberg IH, Vo-Khactu $\mathrm{K}$, Sandstead $\mathrm{HH}$. Plasma trace metals during total parenteral alimentation. Gastroenterology 1976; 70: 1022-5.

18 Jeejeebhoy KN, Chu RC, Marliss EB, Greenberg GR, Bruce-Robertson A. Chromium deficiency, glucose intolerance, and neuropathy reversed by chromium supplementation, in a patient receiving long-term total parenteral nutrition. Am J Clin Nutr 1977; 30: 531-8.

19 Abumrad NN, Schneider AJ, Steel D, Rogers LS. Amino acid intolerance during prolonged total parenteral nutrition reversed by molybdate therapy. Am J Clin Nutr 1981; 34: 2551-9.

20 Rotruck JT, Pope Al, Ganther HE, Swanson AB, Hafeman DG, Hoeckstra WG. Selenium: biochemical role as a component of glutathione peroxidase. Science 1973; 179: 588-90.

21 Forstrom JW, Zakowski JJ, Tappel AL. Identification of the catalytic site of rat liver glutathione peroxidase as selenocysteine. Biochem 1978; 17: 2639-44.

22 Stadtman TC. Selenium-dependent enzymes. Ann Rev Biochem 1980; 49: 93-110.
23 Thomson CD, Rea HM, Doesburg VM, Robinson MF. Selenium concentrations and glutathione peroxidase activities in whole blood of New Zealand residents. $\mathrm{Br}$ J Nutr 1977; 37: 457-60.

24 Thomson CD, Robinson MF. Selenium in human health and disease with emphasis on those aspects peculiar to New Zealand. Am J Clin Nutr 1980; 33: 303-23.

25 Lane HW, Dudrick S, Warren DC. Blood selenium levels and glutathione-peroxidase activities in university and chronic intravenous hyperalimentation subjects. Proc Soc Exptl Biol Med 1981; 167: 383-90.

26 Behne D, Wolters W. Selenium content and glutathione peroxidase activity in the plasma and erythrocytes of non-pregnant and pregnant women. J Clin Chem Clin Biochem 1979; 17: 133-5.

27 Willett WC, Morris JS, Pressel S, et al. Prediagnostic serum selenium and risk of cancer. Lancet 1983; 2: $130-4$.

28 Keshan Disease Research Group of the Chinese Academy of Medical Sciences. Observations on effect of sodium selenite in prevention of Keshan disease. Chin Med J 1979; 92: 471-6.

29 Keshan Disease Research Group of the Chinese Academy of Medical Sciences. Epidemiologic studies on the etiologic relationhip of selenium and Keshan disease. Chin Med J 1979; 92: 477-82.

30 Smith JL, Goos SM. Selenium nutriture in total parenteral nutrition: intake levels. J Parent Ent Nutr $1980 ; 4:$ 23-6.

31 Huston RK, Benda GI, Carlson CV, Shearer TR, Reynolds JW, Neerhout RC. Selenium and vitamin E sufficiency in premature infants requiring total parenteral nutrition. J Parent Ent Nutr 1982; 6: 507-10.

32 Burk RF. Selenium in man. In: Prasad AS, ed. Trace elements in human health and disease. Vol 2. New York: Academic Press, 1976: 105-33.

33 Best WR, Becktel JM, Singleton JW, Kern Jr F. Development of a Crohn's disease activity index. National cooperative Crohn's disease study. Gastroenterology 1976; 70: 439-44. 